\title{
High Salinity Induces Differential Oxidative Stress Responses in Cowpea Genotypes at Early Seedling Stage
}

\author{
Shiddharth Dawkar ${ }^{1}$, Abhijit Arun Daspute ${ }^{1,2^{*}}$, Amar Ramesh Kadam ${ }^{3}$, \\ Jay Prakash Awasthi ${ }^{4}$, Arbind K. Choudhary ${ }^{5}$, B. Fakrudin ${ }^{6}$ and Shiv Sewak ${ }^{7}$ \\ ${ }^{1}$ Department of Plant Biotechnology, College of Agricultural Biotechnology, \\ Vidyaprathishthan, Baramati, MPKV, Rahuri, MS, India \\ ${ }^{2}$ Department of Plant Biotechnology, College of Agricultural Biotechnology, Madadgaon, \\ $M P K V$, Rahuri, $M S$, India \\ ${ }^{3}$ Department of Plant Biotechnology, College of Agricultural Biotechnology, Wadala, MPKV, \\ Rahuri, MS, India \\ ${ }^{4}$ Department of Botany, Govt. College Lamta, Balaghat, MP, India \\ ${ }^{5}$ ICAR Research Complex for Eastern Region, Patna, Bihar, India \\ ${ }^{6}$ Department of Biotechnology and Crop Improvement, College of Horticulture, UHS Campus, \\ GKVK post, Bengaluru, Karnataka, India \\ ${ }^{7}$ All India Network Research Project on Arid Legumes, Indian Institute of Pulses Research, \\ Kanpur, Uttar Pradesh, India \\ *Corresponding author
}

\section{A B S T R A C T}

Keywords

Cowpea, Oxidative stress, Salt stress,

Sensitive genotypes, Tolerant genotypes

Article Info

Accepted:

22 January 2021

Available Online:

10 February 2021
Cowpea (Vigna unguiculata (L.) Walp.) is one of the most important grain legumes worldwide, and its production is affected by increasing soil salinity due to global climate change. In the present study, fourteen genotypes were tested for their salt tolerance at different concentrations of salinity; 0, 100, 150 and $200 \mathrm{mM}$ of $\mathrm{NaCl}$. The relative shoot length, relative fresh weight of whole plant, fresh root weight, relative water content, electrolyte leakage, malondialdehyde (MDA), proline and chlorophyll parameters were investigated. The results showed that growth of seedling, photosynthetic pigments parameters, relative water content were decreased significantly, and MDA, proline content and electrolyte leakage were increased under salinity stress compared to the control circumstances. This study revealed that KBC-2 and KM-5 amongst the fourteen genotypes showed salinity stress tolerance. These two salt tolerant genotypes KBC- 2 and KM- 5 can be used further in breeding program to develop salt tolerance in cowpea lines.

\section{Introduction}

Cowpea [Vigna unguicalata (L.) Walp.] is a diploid legume species $(2 \mathrm{n}=2 \mathrm{x}=22)$ widely grown in Africa, Asia, southern Europe, the Middle East, western United States and South and Central America. Cowpea is cultivated on more than 14 million hectares (Singh et al., 
2003) and the worldwide grain production is estimated to be 5.4 million tons annually, Africa is the leading producer (FAOSTAT, 2016). It is a source of good-quality nutrition for human consumption (Frota et al., 2008), and can be used as cover crop to protect soils eradiation. In the western part of the United States, a growing interest of cowpea as a cover crop has been noticed since it tolerates drought conditions (Agbicodo et al., 2009). Cowpea is a spread legume representing about $80 \%$ of the total production of grains, as green vegetable and dry beans. Like bean, this crop is grown thoroughly in India, Africa and Brazil, constituting an important source of protein (23-30\%) and carbohydrate (56-68\%) (Bressani, 1993).

Agricultural productivity is severely affected by soil salinity and the damaging effect of salt accumulation in agricultural soils (Jaleel et $a l ., 2007)$. Saline environments can reduce a wide number of responses in plants, including readjustment of transport and metabolic processes, leading to growth inhibition. Most crop plants exhibit considerable hypersensitivity to saline environments because inter cellular accumulation of $\mathrm{Na}^{+}$is toxic to cellular metabolism, and for many salt-sensitive plants excess $\mathrm{Na}+$ in the soil plays a major role in growth inhibition (Greenway and Munns, 1980).

Salinity is one of the major limiting factors that have been constraining agricultural production globally (Allakhverdiev et al., 2000). In crop lands, salinity is due to an undesirable increase in the concentration of cations such as $\mathrm{Mg}^{2+}, \mathrm{K}^{+}, \mathrm{Na}^{+}$and $\mathrm{Ca}^{2+}$ and anions such as $\mathrm{HCO}^{3-}, \mathrm{Cl}^{-}, \mathrm{SO}_{4}{ }^{2-}$, and $\mathrm{NO}^{3-}$ (Wallender and Tanji 2011). However, salinity due to sodium chloride $(\mathrm{NaCl})$ has been predominant (Ayers and Westcot, 1985); hence, tolerance to this type of salt was reported in this current investigation. Multiple factors such as rock weathering, poor quality of irrigation water, deforestation and inadequate fertilization - practices can worsen salinity on cultivated lands (Omami and Hammes, 2006). Studies have shown that salt stress can cause serious threats to cowpea production. Cowpea germination has been shown to be unfavorably affected by salt stress (Zahedi et al., 2012). Salt-stressed cowpea plants exhibited a reduced plant growth and vigor (Mini et al., 2015). Salt stress can impair plant physiology, photosynthesis, and absolutely important functions such as cell extension and division (Maas and Hoffman, 1977). These aforementioned factors could lead to a significant cowpea yield reduction (Dutta and Bera, 2014). Breeding for cowpea salttolerant cultivars is one of the most affordable solutions to tackle these issues. However, few studies have focused on addressing salt stress in cowpea in efforts to adequately providing breeders with critical information on the tolerance of cowpea genotypes to salinity. Our studies provide a detailed knowledge of physiological, morphological, and biochemical changes due to $\mathrm{NaCl}$ in fourteen cowpea genotypes during early seedling stage.

\section{Materials and Methods}

\section{Plant material and salt treatment}

A total of fourteen cowpea genotypes viz., VBN-1, KBC-2, KBC-9, IT-38956-1, C-152, RC-19, GC-3, TUX-944, GC-9, KM-5, GC-4, VBN-3, GC-5 and RC-101 were used in the present study (Table 1). The seedlings were grown in seedling tray (6 seedlings/ tray) containing a mixture of $100 \%$ cocopeat in greenhouse. Each tray containing 14 genotypes with 3 replications were maintained throughout the experiment. Watering of cowpea plants was done daily with $500 \mathrm{ml}$ distilled water for up to 3 days and subsequently, irrigated with Hoagland 
nutritive solution (1:10 dilution in water) up to the $10^{\text {th }}$ day after sowing. The ten day old cowpea seedlings were treated with varying salt concentrations by irrigating the tray with $0 \mathrm{mM}, 100 \mathrm{mM}, 150 \mathrm{mM}$ and $200 \mathrm{mM} \mathrm{NaCl}$ solution for 6 days. Thereafter, seedlings were subjected to morphological, physiological and biochemical analysis.

\section{Morphological analysis during salt stress}

For shoot length measurement, the shoots were put on graph papers and photographed. The images were investigated with the assistance of Image programming (Obiefuna and Ndubizu, 1979). To calculate the biomass and fresh root weight, ten whole seedlings and roots respectively, were considered for mean value calculation.

\section{Evaluation of relative water content (RWC)}

Leaf RWC was determined as described earlier with slight modifications (Turner et al., 1981). The leaves from the control (unstressed) and stressed seedlings were sampled and fresh weight (FW) was recorded. The leaf samples were then soaked in water for $4 \mathrm{~h}$ at $25^{\circ} \mathrm{C}$, surface dried and turgid weight (TW) was recorded. Next, the samples were dried in oven at $70^{\circ} \mathrm{C}$ until constant weight was achieved and dry weight (DW) was recorded. RWC was expressed in a percentage according to the following equation: $\mathrm{RWC}=(\mathrm{FW}-\mathrm{DW}) /(\mathrm{TW}-$ DW) $\times 100$.

\section{Determination of electrolyte leakage and lipid peroxidation}

Electrolyte leakage, as an estimate of membrane stability, was determined as described previously (Bhushan et al., 2007). Leaf tissues (100 mg) were collected, for each treatment, in triplicates and incubated for $4 \mathrm{~h}$ in $30 \mathrm{~mL}$ deionized water. An initial reading of the conductance was recorded $\left(\mathrm{C}_{\text {initial }}\right)$ using a conductivity meter (Labman Scientific Instruments, India). The tissues were then autoclaved at $121{ }^{\circ} \mathrm{C}$ for $20 \mathrm{~min}$. The solution was then allowed to cool at $25{ }^{\circ} \mathrm{C}$ and the conductance was re-recorded $\left(\mathrm{C}_{\max }\right)$. Electrolyte leakage was calculated as a percentage of Cinitial to Cmax according to the following formula: $\left(1-\left(\mathrm{C}_{\text {initial }} / \mathrm{C}_{\max }\right)\right)$ $\times 100$. The degree of lipid peroxidation level was determined in terms of malondialdehyde (MDA) content as described previously (Chakraborty et al., 1992). The $200 \mathrm{mg}$ of leaf tissue was homogenized in $2 \mathrm{~mL}$ of $5 \%$ trichloroacetic acid (TCA) and the homogenate was centrifuged at $10,000 \times \mathrm{g}$ for $10 \mathrm{~min}$. One part of the supernatant was added to a tube containing 4 parts of $0.5 \%$ $(\mathrm{v} / \mathrm{v})$ thiobarbituric acid prepared in $20 \%$ (v/v) TCA.

The mixture was heated in a water bath at 95 ${ }^{\circ} \mathrm{C}$ for $30 \mathrm{~min}$ and then cooled to $25{ }^{\circ} \mathrm{C}$. The absorbance of supernatant was determined at $532 \mathrm{~nm}$ and $600 \mathrm{~nm}$. MDA was calculated according to the following formula: $\left(\left(\mathrm{A}_{532}-\mathrm{A}_{600}\right) \times\right.$ volume $\left.\left.\times 100\right) /(155 \times \mathrm{FW})\right)$ and expressed in $\mu \mathrm{mol} \mathrm{mg-1} \mathrm{FW} \mathrm{(Bhushan} \mathrm{et}$ al., 2007).

\section{Analysis of proline content}

Extraction of free proline was performed as described (Bates 1973), with minor modifications. In brief, approximately $100 \mathrm{mg}$ of leaf tissue was homogenized in $3 \%$ sulfosalicylic acid and centrifuged at $5000 \times \mathrm{g}$ for $5 \mathrm{~min}$. The proline content was quantified by mixing the supernatant with equal amount of glacial acetic acid and ninhydrin reagent. The mixture was then kept for $1 \mathrm{~h}$ at $95^{\circ} \mathrm{C}$ in a water bath.

The reaction was terminated by placing the samples on ice. This was followed by addition 
of $4 \mathrm{~mL}$ of toluene in the mixture and shaken vigorously. The toluene layer was then taken to measure absorbance at $520 \mathrm{~nm}$ spectrophotometrically using toluene as blank. Free proline was quantified according to the following formula: $36.6 \times \mathrm{A}_{520} \times$ volume / $2 \times \mathrm{FW}$ and expressed in $\mu \mathrm{mol} \mathrm{g}-1$ FW.

\section{Quantitative determination of chlorophyll}

Chlorophyll was extracted and estimated as described by Lichtenthaler (Lichtenthaler et al., 1987). Approximately, $100 \mathrm{mg}$ leaf sample was homogenized in $80 \%$ chilled acetone and the homogenate was centrifuged at $3000 \times \mathrm{g}$ for $5 \mathrm{~min}$ at $4^{\circ} \mathrm{C}$.

The supernatant was collected and absorbance was measured spectrophotometrically at 663, 645 and $470 \mathrm{~nm}$. Contents of chlorophyll a (Chl a), chlorophyll b (Chl b) in the leaf samples were calculated according to following formulae and expressed in $\mathrm{mg} \mathrm{g}-1$ FW: Chl a $(\mathrm{mg} \mathrm{g}-1)=\left(\left(12.7 \times \mathrm{A}_{663}\right)-(2.69\right.$ $\left.\left.\times \mathrm{A}_{645}\right) \mathrm{v} / \mathrm{w}\right) ; \mathrm{Chl} \mathrm{b}(\mathrm{mg} \mathrm{g}-1)=\left(\left(22.9 \times \mathrm{A}_{645}\right)-\right.$ $\left.\left(4.68 \times \mathrm{A}_{663}\right) \mathrm{v} / \mathrm{w}\right) ; \mathrm{Crd}(\mathrm{mg} \mathrm{g}-1)=((1000 \times$ $\left.\mathrm{A}_{470}\right)-((3.27 \times \mathrm{Chl} \mathrm{a})+(1.04 \times \mathrm{Chl} b)) / 227$ $\mathrm{v} / \mathrm{w})$; Total Chl $(\mathrm{mg} \mathrm{g}-1)=\left(20.2 \times \mathrm{A}_{645}+8.02\right.$ $\left.\times \mathrm{A}_{663}\right)$.

\section{Statistical analysis}

The entire experiment was conducted at College of Agricultural Biotechnology, Baramati during the year 2019. The entire experiment was repeated 3 times to validate the preceding results. All the obtained information was evinced as mean $(n=10)$ followed by standard error (mean \pm SE) format using SPSS 21 (Windows version) software. Furthermore, difference among the various treatments was determined by employing ANOVA (analysis of variance) and post hoc Tukey's HSD (honest significant difference) test at 0.05 level of significance.

\section{Results and Discussion}

\section{Morphological changes in cowpea seedlings}

To examine the effect of high salt stressinduced morphometric alterations, ten days old seedlings were exposed to salt stress for duration of six days at $0 \mathrm{Mm}, 100 \mathrm{mM}, 150$ $\mathrm{mM}$ and $200 \mathrm{mM} \mathrm{NaCl}$ concentrations. Seedlings of all the fourteen genotypes showed the visible stress symptoms such as leaf chlorosis and leaf rolling. However, KBC-2 and KM-5 showed minimal chlorosis and rolling even on the sixth day. The seedlings of KBC-9, RC-19, TUX-944, GC-9, and RC-101 showed severe visible symptoms, but KBC-2, IT-38956-1 and KM-5 showed minimal symptoms even at $200 \mathrm{mM} \mathrm{NaCl}$ (Fig. 1). Several researchers have reported similar results in cowpea under salinity stress (Mishra et al., 2014; Taffouo et al., 2009).

\section{Effect of high salt stress on biomass and shoot length}

To assess the effect of high salinity on cowpea growth, the biomass (fresh weight of whole plant), fresh root weight and shoot length of seedlings were measured (Fig. 2, 3, 4). Increase in the $\mathrm{NaCl}$ concentration resulted in significant decrease in the fresh weight, fresh root weight and relative shoot length of several genotypes such as KBC-9 and RC-101. However, genotype KBC-2 and KM-5 showed no statistical difference in the biomass, fresh root weight and relative shoot length compared to the controls (Fig. 2, 3, 4). This suggests that severe salinity reduced growth progressively from shoot along the vertical gradient to the cowpea plant. The previous several study reports revealed reduction in shoot, root and biomass of plant exposed to salt, drought, aluminum and cadmium stress (Chowardhari et al., 2019; Awasthi et al., 2017; Saha et al., 2016; Mishra et al., 2014). 
Table.1 Description of cowpea genotypes

\begin{tabular}{|c|c|c|}
\hline S. No. & Genotypes & Salient features \\
\hline 1. & VBN-1 & $\begin{array}{l}\text { A variety released in } 1998 \text { for cultivation in rainfed areas of Tamil } \\
\text { Nadu and Karnataka; late type ( } 90-100 \text { days), yellowish white flower, } \\
\text { long pods, large size creamy white seed; yield potential: } 950-1100 \\
\mathrm{~kg} / \mathrm{ha} \text {. }\end{array}$ \\
\hline 2. & $\mathrm{KBC}-2$ & $\begin{array}{l}\text { A late maturing variety released in } 1998 \text { for cultivation in Karnataka } \\
\text { and Tamil Nadu; asynchronous maturity, long pods, light brown } \\
\text { seeds; tolerance to rust; yield potential: } 600-1200 \mathrm{~kg} / \mathrm{ha} \text {. }\end{array}$ \\
\hline 3. & KBC-9 & $\begin{array}{l}\text { A medium duration ( } 80-85 \text { days) variety released in } 2018 \text { for } \\
\text { cultivation in southern states (Karnataka, Tamil Nadu, Andhra } \\
\text { Pradesh and Kerala); resistant to collar rot, moderate resistance to } \\
\text { yellow mosaic virus (YMV); good and stable yield (1100-1200 } \\
\mathrm{kg} / \mathrm{ha} \text { ). }\end{array}$ \\
\hline 4. & IT-38956-1 & A grain purpose older variety released for cultivation in Karnataka. \\
\hline 5. & RC-19 & $\begin{array}{l}\text { An old variety released in } 1993 \text { for cultivation in Rajasthan; early (65- } \\
70 \text { days) and synchronous maturity, moderately resistant to YMV; } \\
\text { white seed with good yield potential (900-1000 kg/ha). }\end{array}$ \\
\hline 6. & GC-3 & $\begin{array}{l}\text { A nationally adapted, drought tolerant and disease resistant variety } \\
\text { released in } 1997 \text { for states of central zone (Gujarat and Maharashtra), } \\
\text { south zone (Karnataka and TN), north-east plain (Jharkhand) and } \\
\text { north-west plain (Delhi); short stature, late maturing (90-95 days) and } \\
\text { good yield potential ( } 750-1150 \mathrm{~kg} / \mathrm{ha} \text { ). }\end{array}$ \\
\hline 7. & TUX-944 & $-\mathrm{NA}-$ \\
\hline 8. & C-152 & $\begin{array}{l}\text { An older variety having medium maturity duration ( } 85-90 \text { days) } \\
\text { released in } 1985 \text { for cultivation in Karnataka; light coloured seed; } \\
\text { susceptible to rust. }\end{array}$ \\
\hline 9. & GC-9 & $-\mathrm{NA}-$ \\
\hline 10. & KM-5 & $\begin{array}{l}\text { A high-yielding variety released after } \mathrm{C}-152 \text { for cultivation in } \\
\text { northern transitional zone of Karnataka; its superiority over C-152 } \\
\text { owes to its greater height and more number of branches; resistant to } \\
\text { powdery mildew and rust. }\end{array}$ \\
\hline 11. & $\mathrm{GC}-4$ & $\begin{array}{l}\text { An early ( } 58-70 \text { days) variety with synchronous maturity released in } \\
1998 \text { for cultivation in Gujarat; moderately resistant to YMV with } \\
\text { good yield potential }(900-1000 \mathrm{~kg} / \mathrm{ha} \text { ). }\end{array}$ \\
\hline 12. & VBN-3 & $\begin{array}{l}\text { A variety released after } \mathrm{VBN}-1 \text { for cultivation in Tamil Nadu; early } \\
\text { type ( } 75-80 \text { days), light purple flower, long pods, large size light } \\
\text { brown seed; yield potential: } 1100-1300 \mathrm{~kg} / \mathrm{ha}\end{array}$ \\
\hline 13. & GC-5 & $\begin{array}{l}\text { A long-duration (94-100 days) and high yielding }(1100 \mathrm{~kg} / \mathrm{ha}) \text { variety } \\
\text { released in } 2005 \text { for the state of Gujarat; moderately resistant to } \\
\text { YMV. }\end{array}$ \\
\hline 14. & RC-101 & $\begin{array}{l}\text { An extra early ( } 60-65 \text { days) and determinate variety released in } 2001 \\
\text { for cultivation in the state of Rajasthan; non-viny, white seeded with } \\
\text { good yield potential }(750-850 \mathrm{~kg} / \mathrm{ha}) \text {; drought tolerant and suitable for } \\
\text { low rain fall areas. }\end{array}$ \\
\hline
\end{tabular}


Fig.1 Salt stress induced morphological changes in developing cowpea seedlings. Cowpea genotypes were grown and monitored under control and salt stress conditions (100, 150,200 $\mathrm{mM}$ ) for 6 days. The experiments were carried out in triplicates and data represented is the mean of the replicates. Histograms with different alphabets depict the statistical significance at $\mathrm{P}$ value $<0.05$

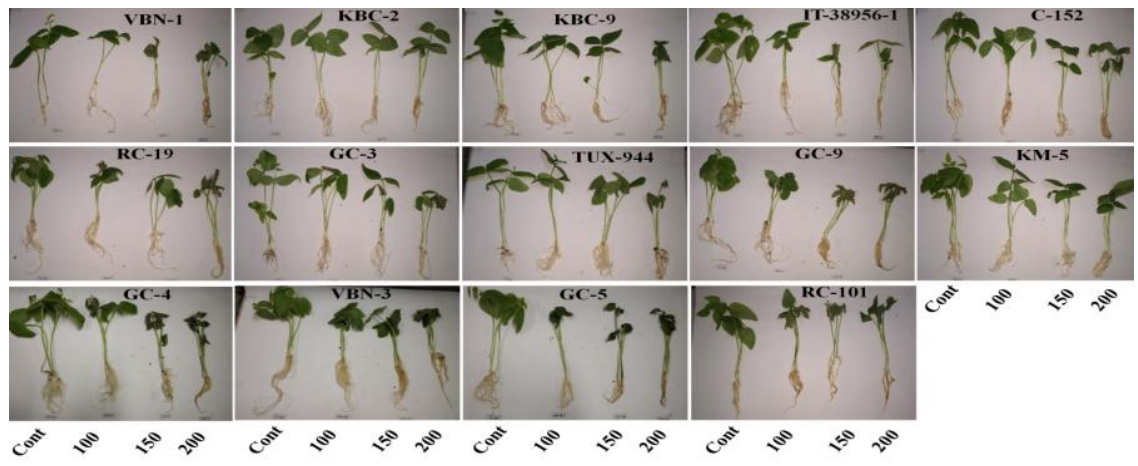

Fig.2 Assessment of physicochemical parameters (relative fresh weight) under control and salt stress conditions among all cowpea genotypes. The experiments were carried out in triplicates and data represented is the mean of the replicates. Histograms with different alphabets depict the statistical significance at $\mathrm{P}$ value $<0.05$

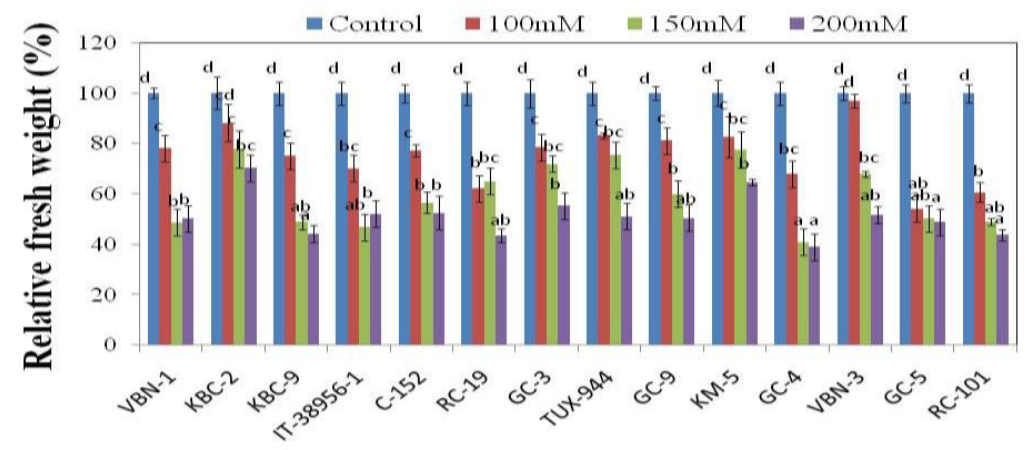

Fig.3 Assessment of physicochemical parameters (relative fresh root weight) under control and salt stress conditions among all cowpea genotypes. The experiments were carried out in triplicates and data represented is the mean of the replicates. Histograms with different alphabets depict the statistical significance at $\mathrm{P}$ value $<0.05$

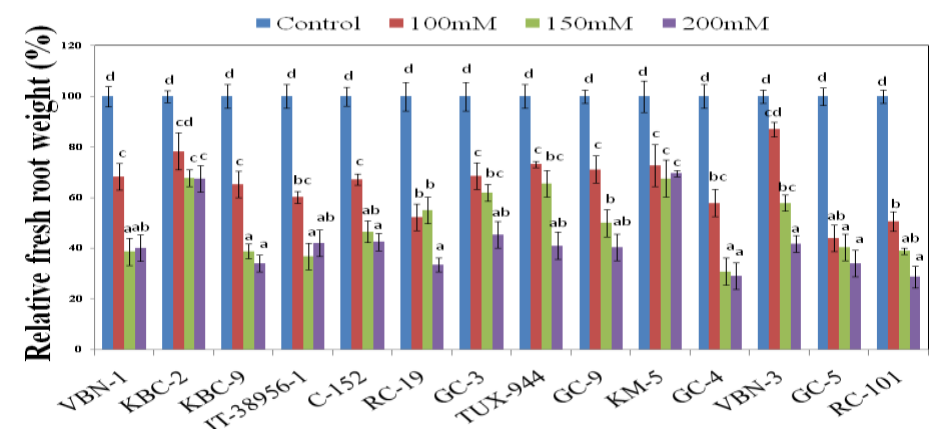


Fig.4 Assessment of physicochemical parameters (relative shoot weight) under control and salt stress conditions among all cowpea genotypes. The experiments were carried out in triplicates and data represented is the mean of the replicates. Histograms with different alphabets depict the statistical significance at $\mathrm{P}$ value $<0.05$

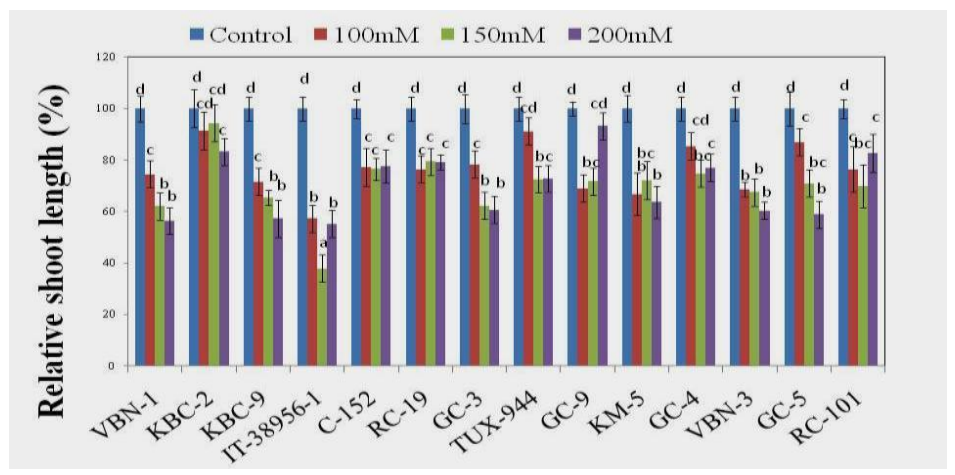

Fig.5 Assessment of biochemical parameters (relative water content) under control and salt stress conditions among all cowpea genotypes. The experiments were carried out in triplicates and data represented is the mean of the replicates. Histograms with different alphabets depict the statistical significance at $\mathrm{P}$ value $<0.05$

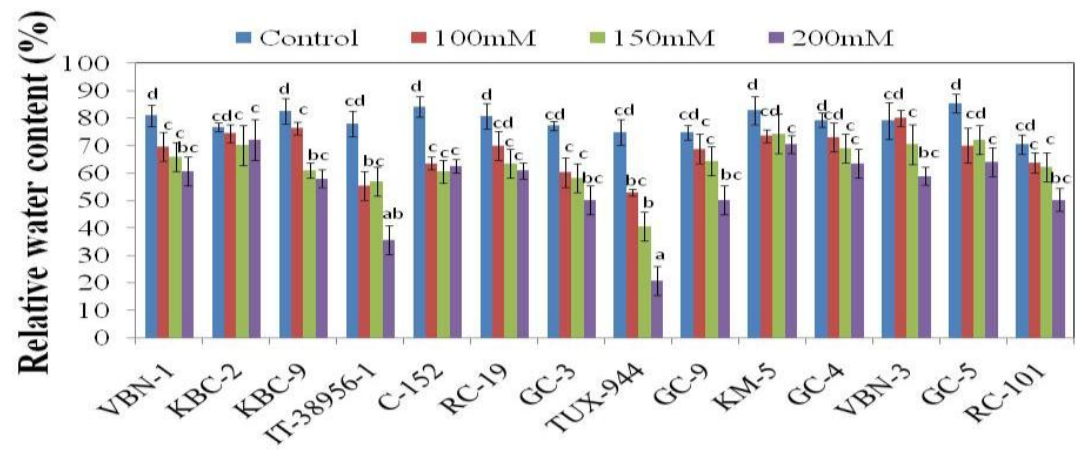

Fig.6 Assessment of biochemical parameters (electrolyte leakage) under control and salt stress conditions among all cowpea genotypes. The experiments were carried out in triplicates and data represented is the mean of the replicates. Histograms with different alphabets depict the statistical significance at $\mathrm{P}$ value $<0.05$

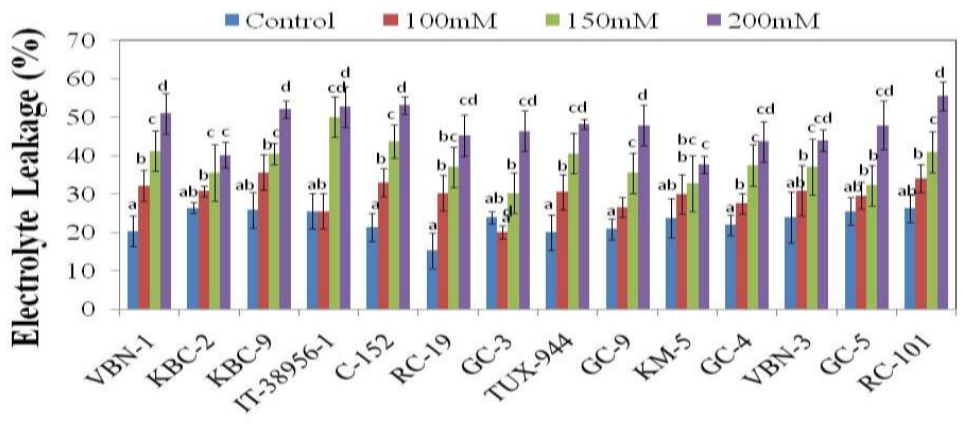


Fig.7 Assessment of biochemical parameters (MDA) under control and salt stress conditions among all cowpea genotypes. The experiments were carried out in triplicates and data represented is the mean of the replicates. Histograms with different alphabets depict the statistical significance at $\mathrm{P}$ value $<0.05$

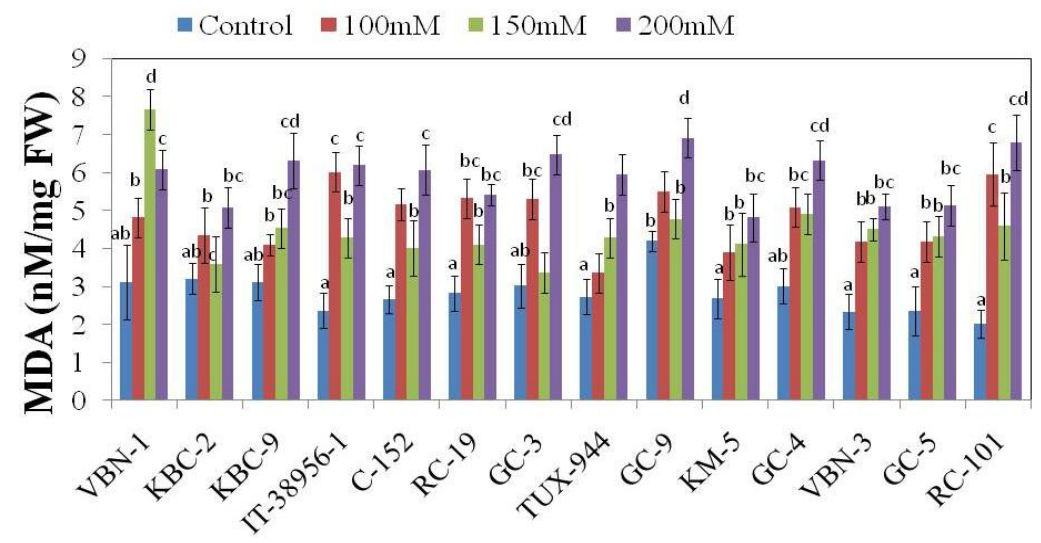

Fig.8 Assessment of biochemical parameters (proline) under control and salt stress conditions among all cowpea genotypes. The experiments were carried out in triplicates and data represented is the mean of the replicates. Histograms with different alphabets depict the statistical significance at $\mathrm{P}$ value $<0.05$

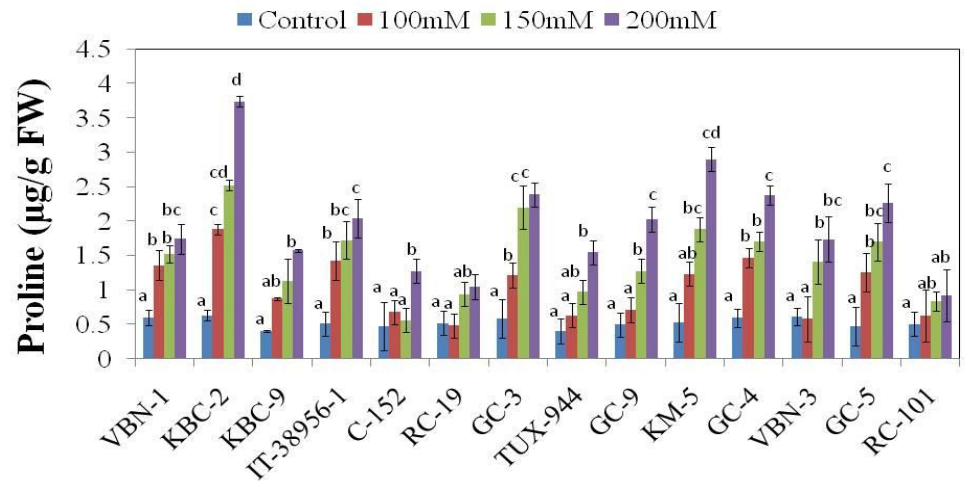

Fig.9 Evaluation of photosynthetic pigments (chlorophyll a) among all cowpea genotypes

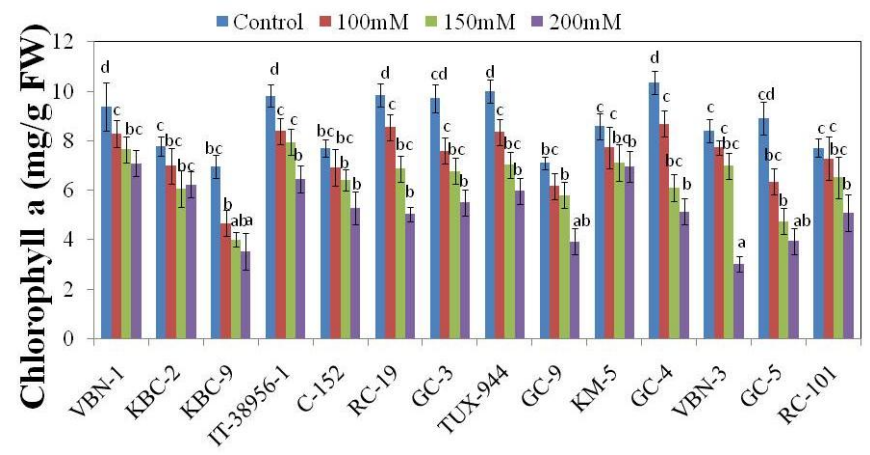


Fig.10 Evaluation of photosynthetic pigments (chlorophyll b) among all cowpea genotypes

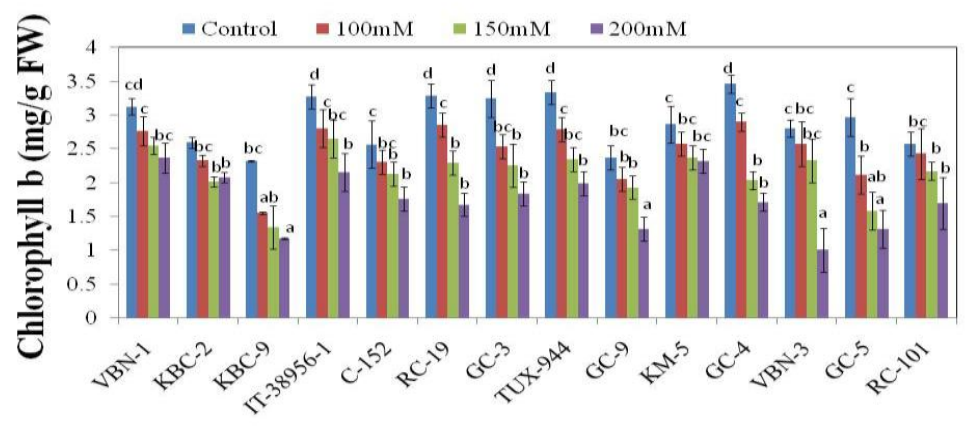

Fig.11 Evaluation of photosynthetic pigments (total chlorophyll) among all cowpea genotypes

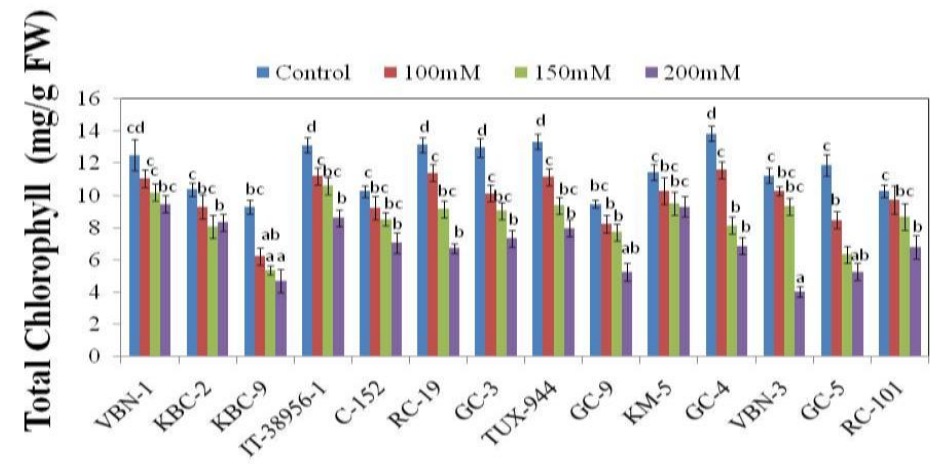

\section{Effect of salinity on plant water status}

Salinity-imposed osmotic stress leads to cell turgor loss and cell volume change and therefore, we examined the water status of the seedlings. Initially, RWC was found to be decreased in all the cultivars by $\mathrm{NaCl}$ stress. Significant decrease in RWC was observed in all genotypes except KBC-2, KM-5 and GC4. The maximum decrement in RWC was observed in TUX-944 ( 54\%) and IT 38956$1(\sim 42 \%)$, but minimum in $\mathrm{KBC}-2(\sim 4 \%)$ and KM-5 ( 12\%) (Fig. 5). The previous study revealed that the salinity decreased RWC and water retention capacity, while increased water saturation deficit and water uptake capacity in mung bean (Kabir et al., 2004). The RWC is an indicator of water status in leaves. Control plant seedling maintained a high water status as compared with stressed seedling. Earlier reports (Mishra et al., 2014;
Gouiaa et al., 2012) also suggested similar results.

\section{Effect of salinity on membrane integrity}

We critically monitored the status of membrane integrity of the seedlings exposed to salt stress in terms of the extent of electrolyte leakage. Electrolyte leakage showed significant increment in most of the genotypes with increasing salt concentration. Minimum increment ( 38-40\%) of electrolyte leakage was observed in $\mathrm{KM}-5$ and KBC-2, whereas C-152 and RC-101 showed maximum increase ( 55-53\%) (Fig. $6)$. Several previous studies have reported that various stresses such as salt, drought, aluminum, high temperature and cadmium account for the production of reactive oxygen species (ROS), leading to membrane damage (Chowardhara et al., 2019 Awasthi et al., 
2017; Saha et al., 2016; Chakraborty and Pradhan, 2010). Stress induced membrane fluidity is a key factor for membrane damage (Ruelland \& Zachowski, 2010), and increased membrane fluidity is closely related to electrolyte leakage (Bhushan et al., 2007). Therefore, high salt induced minimum membrane damage was observed in the genotypes KBC-2 and KM-5, thus it showed minimum increment in electrolytic leakage. Several workers (Tuna et al., 2008, 2007; Kaya et al., 2007; Ghoulam et al., 2002; Lutts et al., 1996, 1999) reported that electrolyte leakage increased in the leaves of tomato plants grown under salt stress.

\section{Effect of salinity on lipid peroxidation}

The $\mathrm{NaCl}$ stress induced peroxidation of membrane lipids, which was determined by MDA concentration. The MDA has been widely used as a selection criterion to assess salt injury in various plants (Jaleel et al., 2007 Katsuhara et al., 2005). The MDA concentration was significantly increased in the stressed seedlings. Minimum lipid peroxidation was observed in KBC-2 $(\sim 20 \%)$ and KM-5 ( 20\%), as against RC-101 ( 50 $\%)$ and IT 38956-1 ( 40 \%) (Fig. 7). These results suggest that KBC-2 and KM-5 could better maintain cell membrane homeostasis and integrity under high salt stress. The MDA which is often used as an indicator of oxidative damage and effects of oxidative stress on membrane integrity are frequently evaluated through the increases in MDA concentration, is produced during peroxidation of membrane lipid by decomposition of polyunsaturated fatty acid (Sanchez-rodriguez et al., 2010; Pinheiro et al., 2004; Bor et al., 2003). In our present study, we observed that the minimum MDA content was increased by about 2 fold at 200 $\mathrm{mM} \mathrm{NaCl}$ concentrations in $\mathrm{KBC}-2$ and $\mathrm{KM}$ 5. The level of MDA is considered as a biomarker of stress and increased as severity of stress increased. Guimaraes et al., (2011) showed that increased MDA content might result in electrolyte leakage, indicating a loss of membrane integrity. These obtained results are similar to those obtained by Sadak et al., (2017) on chickpea plant and by El-Awadi et al., (2017) on faba been plant.

\section{Effect of $\mathrm{NaCl}$ on proline accumulation}

Accumulation of osmolytes especially proline is a well-known adaptive response in plants against environmental stress conditions including high salt stress. The proline content significantly increased in all the genotypes treated with salt stress compared to respective controls. Here, KBC-2 (30 \%) showed the highest accumulation, whereas RC-101 did not record any induction of proline under 200 $\mathrm{mM} \mathrm{NaCl}$ stress (Fig. 8). The compatible solutes, particularly proline, contribute a significant role in osmotic adjustment and structural stability during stress (Wahid et al., 2007). Indeed, cellular machinery releases the compatible solutes to maintain the redox potential under high salt stress. Increased accumulation of proline was thus in agreement with these findings, as maximum proline accumulation was observed in $\mathrm{KBC}-2$ (Fig. 8). Accumulation of proline in response to various stresses in leaf have been reported previously in many studies (Eraslan et al., 2007; Tarakcioglu and Inal, 2002; Aziz et al., 1999), which (proline) is responsible for detoxifying ROS by forming a stable complex with them, and thus inhibits the process of lipid peroxidation (Xiong and Zhu, 2002). It is increasingly clear that plants accumulate proline to avoid water loss under stress conditions and maintain the cell water balance. The increased proline accumulation at early stage of salt treatment could be positively correlated with the preventive maintenance of RWC. The accumulation of the proline in plant tissues in response to different abiotic stresses may play an 
important role against oxidative damages (Alia et al., 2001), take part in cellular osmotic adjustment (Yamada et al., 2005), and stabilize the membrane and protein 3D structure (Kavi-kishor et al., 2005; Ashraf and Foolad 2007). Proline is a compatible osmolyte, and performs multiple functions in stress adaptation, recovery and signaling, stabilization of proteins and protein complexes in the chloroplast and cytosol and protection of the photosynthetic apparatus in plants (Szabados, and Savoure, 2009). Ashraf and Foolad (2007) suggested that the application of proline successfully improved stress tolerance in plants.

\section{Effect of salt stress on photosynthetic pigments}

To assess the effects of high salt on the photosynthetic capabilities, the status of photosynthetic pigments viz., chlorophyll a, chlorophyll b and total chlorophyll was analyzed. The seedlings exhibited a drastic decline in photosynthetic pigments with increasing salt concentration. The genotype CG-5 showed the highest reduction $(57 \%)$ of chlorophyll $a$, followed by VBN-3 (50\%) and KM-5 (20\%) at $200 \mathrm{mM} \mathrm{NaCl}$ stress (Fig. 8). Similar phenomenon was observed in case of chlorophyll $b$ and total chlorophyll, upon exposure to $\mathrm{NaCl}$ stress (Fig. 10 and 11). This result indicated that minimum degradation of chlorophyll content in KM-5 genotype under salt stress showed its better photosynthetic ability. Tuna et al., (2007) reported that the both chlorophyll $a$ and $b$ contents of maize plant decreased in response to salinity stress. The reductions in different photosynthetic pigment components in response to salt stress were confirmed by Sadak et al., (2015) and Ismail et al., (2019) on faba bean plant. The decline in photosynthesis due to salinity stress could be due to lower stomata conductance, inhibition of photochemical capacity, depression in carbon uptake and metabolism and a combination of all these factors (Mundree et al., 2002). Moreover, the inhibitory effects of salt stress on chlorophyll pigments could be due to suppression of specific enzymes responsible for the synthesis of the green pigments or due to increased chlorophyllase activity in wheat and mustard (Mishra et al., 2006; Kiani et al., 2005). Photosynthetic pigments decreased in chickpea grown under salt stress (Beltagi 2008) and photosynthesis was reduced to $60 \%$ (Murumkar and Chavan, 1993).

In conclusion the salt stress is second most adversity after drought in agriculture production, and it leads to drastic change in physiological, biochemical and molecular behavior of plants. In terms of physiological parameters, stunted growth, chlorosis, loss of water content and membrane damage were observed in salt sensitive cultivars. The screening of the fourteen cultivars revealed that KBC-2 and KM-5 were salt tolerant even at higher level of salinity. The two KBC-2 and KM-5 salt tolerant genotypes can be used in pre-breeding program to develop salt tolerance in cowpea lines.

\section{Acknowledgement}

We are thankful to Project Nodal Scientist, All India Network Research Project on Arid Legumes for providing seeds of cowpea genotypes. Authors are also thankful to VP College of Agricultural Biotechnology, Baramati for providing all facilities to conduct aforementioned research work.

\section{References}

Agbicodo, E.M., Fatokun, C. A., Muranaka, S., Visser, R.G.F., Linden van der, C.G. (2009). Breeding drought tolerant cowpea: constraints, accomplishments, and future prospects. Euphytica, 167, $353-370$. 
Alia, J. M., Mohanty, P., Matysik, J. (2001). Effect of proline on the production of singlet oxygen. Amino Acids, 21, 195200.

Allakhverdiev, S.I., Sakamoto, A., Nishiyama, Y., Inaba, M., Murata. N. (2000). Ionic and osmotic effects of $\mathrm{NaCl}$ induced inactivation of photosystems I and II in Synechococcus spp. Plant Physiology, 123, 1047-1056.

Ashraf, M. and Foolad, M.R. (2007). Roles of glycine, betaine and proline in improving plant abiotic stress tolerance. Environmental and Experimental Botany, 59, 206-216.

Awasthi, J. P., Saha, B., Regon, P., Sahoo, S., Chowra, U., Pradhan, A., Panda, S. K. (2017). Morpho-physiological analysis of tolerance to aluminum toxicity in rice varieties of North East India. PloS ONE, 12(4), e0176357. https://doi.org/10.1371/journal.pone.017 6357.

Ayers, R.S. and Westcot, D.W. (1985). Water quality for agriculture. FAO irrigation and drainage, Paper 29, FAO, Rome. 97 p.

Aziz, A., Martin-Tanguy, J., Larher, F. (1999). Salt stress-induced proline accumulation and changes in tyramine and polyamine levels are linked to ionic adjustment in tomato leaf discs. Plant Science, 145, 83-91.

Bates, L.S. and Waldren, R.P. (1973). Teare, Rapid determination of free proline for waterstress studies, Plant Soil, 39, 205 207.

Beltagi, M.S. (2008). Exogenous ascorbic acid (vitamin C) induced anabolic changes for salt tolerance in chick pea (Cicer arietinum L.) plants. African Journal of Plant Science, 2, 118-123.

Bhushan, D., Pandey, A., Choudhary, M.K., Datta, A., Chakraborty, S., Chakraborty, N. (2007). Comparative proteomics analysis of differentially expressed proteins in chickpea extracellular matrix during dehydration stress, Molecular and Cell Proteomics, 6, 1868-1884.

Bor, M., Ozdemir, F., Turkan, I. (2003). The effect of salt stress on lipid peroxidation and antioxidants in leaves of sugar beet Beta vulgaris L. and wild beet Beta maritima L. Plant Science, 164, 77-84.

Bressani, R. (1993). Grain quality of common beans. Food Reviews International, 9, 237-297.

Chakraborty, N. and Tripathy, B.C. (1992). Involvement of singlet oxygen in 5aminolevulinic acid-induced photodynamic damage of cucumber (Cucumis sativus L.) chloroplasts, Plant Physiology, 98, 7-11.

Chakraborty, U. and Pradhan, D. (2010). High temperature-induced oxidative stress in Lens culinaris, role of antioxidants and amelioration of stress by chemical pretreatments. Journal of Plant Interactions, 6, 43-52.

Chowardhara, B., Borgohain, P., Saha, B., Awasthi, J. P., Moulick, D., Panda, S. K. (2019). Phytotoxicity of Cd and Zn on three popular Indian mustard varieties during germination and early seedling growth. Biocatalysis and Agricultural Biotechnology, 21, 101349. https://doi.org/10.1016/j.bcab.2019.101 349.

Dutta, P. and Bera, A.K. (2014). Effect of $\mathrm{NaCl}$ Salinity on seed germination and seedling growth of mungbean cultivars. Legume Research, 37, 161-164.

El-Awadi, M.E., Sadak, M.S., Dawood, M.G., Khater, M.A., Elashtokhy, M.M.A. (2017). Amelioration the adverse effects of salinity stress by using $\gamma$-radiation in faba bean plants. Bulletin of National Research Centre, 41, 293-310.

Eraslan, F., Inal, A., Gunes, A., Alpaslan, M. (2007). Boron toxicity alters nitrate reductase activity, proline accumulation, membrane permeability, 
and mineral constituents of tomato and pepper plants. Journal of Plant Nutrition, 30, 981-994.

Frota, K.M.G., Soares, R.A.M., Areas, J.A.G. (2008). Chemical composition of cowpea (Vigna unguiculata L. Walp). Journal of Food Science Technology. 28, 470-476.

Ghoulam, C., Foursy, A., Fares, K. (2002). Effects of salt stress on growth, inorganic ions and proline accumulation in relation to osmotic adjustment in five sugar beet cultivars. Environmental and Experimental Botany, 47, 39-50.

Gouiaa, S., Khoudi, H., Leidi, E.O., Pardo, J.M., Masmoudi, K. (2012). Expression of wheat $\mathrm{Na} / \mathrm{H}$ antiporter TNHXS1 and $\mathrm{H}$ - pyrophosphatase TVP1 genes in tobacco from a bicistronic transcriptional unit improves salt tolerance. Plant Molecular Biology, 79,137-155.

Greenway H, Munns R. (1980). Mechanism of salt tolerance in nonhalophytes. Annu. Rev. Plant Physiology, 31, 149190.

Guimaraes, F.V.A., de Lacerda, C.F., Marques, E.C., de Miranda, M.R.A., de Abreu, C.E.B. (2011). Calcium can moderate changes on membrane structure and lipid composition in cowpea plants under salt stress. Plant Growth Regulation, 65, 55-63.

Ismail, R.R., Ahmad, E.S., Abdel-Fattah, M., Omar, M.N., Azzam, C.R., Zahran, H.H. (2019). Effect of plant growthpromoting rhizobacteria on growth and symbiotic nitrogen fixation of Vicia faba plants under salt stress. Journal of Plant Science, 7, 01-19.

Jaleel, C.A., Gopi, R., Sankar, B., Manivannan, P., Kishorekumar, A., Sridharan, R., Panneerselvam, R. (2007). Studies on germination, seedling vigour, lipid peroxidation and proline metabolism in Catharanthus roseus seedlings under salt stress. South African Journal of Botany, 73, 190-195. Jaleel, C.A., Manivannan, P., Lakshmanan, G.M.A., Sridharan, R., Panneerselvam, R. (2007). $\mathrm{NaCl}$ as a physiological modulator of proline metabolism and antioxidant potential in Phyllanthus amarus. Comptes Rendus Biologies, 330, 806-813.

Kabir M.E., Karim, M.A., Azad, M.A.K. (2004). Effect of Potassium on Salinity Tolerance of Mungbean (Vigana radiata L. Wilczek). Journal of Biological Sciences, 4, 103-110.

Katsuhara, M., Otsuka, T., Ezaki, B. (2005). Salt stress-induced lipid peroxidation is reduced by glutathione S-transferase, but this reduction of lipid peroxides is not enough for a recovery of root growth in Arabidopsis. Plant Science, 169, 369-373.

Kavi-Kishor, P.B., Sangam. S., Amrutha, R.N., Sri Laxmi, P., Naidu, K.R., Rao, K.R.S.S., Rao, S., Reddy, K.J., Theriappan, P., Sreeniv, N. (2005). Regulation of proline biosynthesis, degradation, uptake and transport in higher plants: its implications in plant growth and abiotic stress tolerance. Current Science, 88, 424-438.

Kaya, C., Tuna, A. L, Ashraf, M., Altunlu, H. (2007). Improved salt tolerance of melon (Cucumis melo L.) by the addition of proline and potassium nitrate. Environmental and Experimental Botany, 60, 397-403.

Kiani, A.J.K., Edgar, E.B., Joseph, M.J. (2005). Mechanistic analysis of wheat chlorophyllase. Archives of Biochemistry and Biophysics, 438, 146155.

Lichtenthaler, H.K. (1987). Chlorophyll fluorescence signatures of leaves during the autumnal chlorophyll breakdown, Journal of Plant Physiology. 131, 101110. 
Lutts, S., Kinet, J.M., Bouharmont, J. (1996). $\mathrm{NaCl}$-induced senescence in leaves of rice (Oryza sativa L.) cultivars differing in salinity resistance. Annals of Botany, 78, 389-398.

Lutts, S., Bouharmont, J., Kinet, J.M. (1999). Physiological characterization of saltresistant rice (Oryza sativa L.) somaclones. Australian Journal of Botany, 47, 835-849.

Maas, E.V. and Hoffman, G.J. (1977). Crop salt tolerance-current assessment. Journal of Irrigation and Drainage Division, 103, 115-134.

Mini, M.L., Sathya, K., Arulvadivookarasi, K.S., Jayachandran, Anusuyadevi, M. (2015). Selection of salt tolerant cowpea genotypes based on salt tolerant indices of morphobiochemical traits. Current Trends in Biotechnology and Pharmacy, 9, 306-316.

Mishra, S., Tyagi, A., Singh, I. V., Sangwan, R.S. (2006). Changes in lipid profile during growth and senescence of Catharanthus roseus leaf. Brazilian Journal of Plant Physiology, 18, 447454.

Mishra, S., Behura, R., Awasthi, J. P., Dey, M., Sahoo, D., Bhowmik, S. S. D., Sahoo, L. (2014). Ectopic overexpression of a mungbean vacuolar $\mathrm{Na}+\mathrm{H}+$ antiporter gene (VrNHX1) leads to increased salinity stress tolerance in transgenic Vigna unguiculata L. Walp. Molecular breeding, 34, 1345-1359.

Murumkar, C.V. and Chavan, P.D. (1993). Alterations in photosynthetic carbon metabolism of chickpea (Cicer arietinum L.) due to imposed $\mathrm{NaCl}$ salinity. Agrochimica, 37, 26-32.

Olufajo, O. O. (2012). Agronomic performance of improved cowpea varieties under natural infestation with Alectra vogelii (Benth.) in the Northern Guinea savannah of Nigeria. Journal of
Tropical and Subtropical Agriculture, $45,66-71$.

Obiefuna J.C., Ndubizu T.O.C. (1979). Estimating leaf area of plantain.. Science Horticulture, 11, 31-36.

Omami, E.N. and Hammes, P.S. (2006). Interactive effects of salinity and water stress on growth, leaf water relations, and gas exchange in amaranth (Amaranthus spp.). New Zealand Journal of Crop and Horticultural Science. 87, 1275-1279.

Pinheiro, H.A., Damatta, F.M., Chaves, A.R.M., Fontes, E.P.B., Loureiro, M.E. (2004). Drought tolerance in relation to protection against oxidative stress in clones of Coffea canephora subjected to long-term drought. Plant Science, 167, 1307-1314.

Ruelland, E. and Zachowski, A. (2010) How plants sense temperature. Environmental and Experimental Botany, 69, 225-232.

Sadak, M.S., Abd Elhamid, E.M., Ahmed, M.M.R.M. (2017). Glutathione induced antioxidant protection against salinity stress in chickpea (Cicer arietinum L.) plant. Egyptian Journal of Botany, 57, 293-302.

Sadak, M.S., Abdelhamid, M.T., Schmidhalter, U. (2015). Effect of foliar application of amino acids on plant yield and some physiological parameters in bean plants irrigated with sea water. Acta Biológica Colombiana, 20, 141-152.

Saha, B., Mishra, S., Awasthi, J. P., Sahoo, L., Panda, S. K. (2016). Enhanced drought and salinity tolerance in transgenic mustard [Brassica juncea (L.) Czern \& Coss.] overexpressing Arabidopsis group 4 late embryogenesis abundant gene (AtLEA4-1). Environmental and Experimental Botany, 128, 99-111.

Sanchez-Rodriguez, E., Rubio-Wilhelmi, 
M.M., Cervilla, L.M., Blasco, B., Rios, J.J., Rosales, M.A., Romero, L., Ruiz, J.M. (2010). Genotypic differences in some physiological parameters symptomatic for oxidative stress under moderate drought in tomato plants. Plant Science, 178, 30-40.

Singh, B.B., Ajeigbea, H.A., Tarawalib, S.A., Fernandez-Riverac, S., Musa, A. (2003). Improving the production and utilization of cowpea as food and fodder. Field Crops Research, 84, 169177.

Szabados, L. and Savoure, A. (2009). Proline: a multifunctional amino acid. Trends in Plant Science, 15, 89-97.

Taffouo,V.D., Meguekam, L., Kenne, M., Magnitsop, A., Akoa, A., Ourry, A., Tenywa, J.S. (2009). Stress effects on germination plant growth and accumulation of metabolites in five leguminous plants. 9th African Crop Science Conference Proceedings, Cape Town South Africa. p. 157-161.

Tarakcioglu, C. and Inal A. (2002). Changes induced by salinity, demarcating specific ion ratio $(\mathrm{Na} / \mathrm{Cl})$ and osmolality in ion and proline accumulation, nitrate reductase activity and growth performance of lettuce. Journal of Plant Nutrition, 25, 27-41.

Tuna, A.L., Kaya, C., Ashraf, M., Altunlu, H., Yokas, I., Yagmur, B. (2007). The effects of calcium sulphate on growth, membrane stability and nutrient uptake of tomato plants grown under salt stress. Environmental and Experimental Botany, 59, 1 73-1 78.
Tuna, A. L, Kaya, C., Dikilitas, M., Higgs, D. (2008). The combined effects of gibberellic acid and salinity on some antioxidant enzyme activities, plant growth parameters and nutritional status in maize plants. Environmental and Experimental Botany, 62, 1 -9.

Turner N.C. (1981). Techniques and experimental approaches for the measurement of plant water status, Plant Soil, 58, 339-366.

Wahid, A., Gelani, S., Ashraf, M., Foolad, M. R. (2007). Heat tolerance in plants: an overview. Environmental and Experimental Botany. 61, 199-223.

Wallender, W.W. and Tanji, K.K. (2011). Agricultural salinity assessment and management. $2^{\text {nd }}$ edn. American Society Civil Engineers, Reston, VA. 1094pp.

Xiong, L. and Zhu, J. K. (2002). Molecular and genetic aspects of plant response to osmotic stress. Plant, Cell and Environment, 25, 131-139.

Yamada, M., Morishita, H., Urano, K., Shiozaki, N., Yamaguchi-Shinozaki, K., Shinozaki, K., Yoshiba, Y. (2005). Effects of free proline accumulation in petunias under drought stress. Environmental and Experimental Botany, 56, 1975-1981.

Zahedi, S.M., Ansari, N.A., Azizi, M. (2012). The study of the effect of salinity stress on the germination and the initial growth of cowpea (Vigna unguiculata L. Walp). Journal of Agricultural Technology. 8, 2353-2372

\section{How to cite this article:}

Shiddharth Dawkar, Abhijit Arun Daspute, Amar Ramesh Kadam, Jay Prakash Awasthi, Arbind K. Choudhary, B. Fakrudin and Shiv Sewak. 2021. High Salinity Induces Differential Oxidative Stress Responses in Cowpea Genotypes at Early Seedling Stage. Int.J.Curr.Microbiol.App.Sci. 10(02): 2976-2990. doi: https://doi.org/10.20546/ijcmas.2021.1002.326 